\title{
Updated meta-analysis of the relation between heart disease and androgenic
}

\section{alopecia or alopecia areata}

\author{
Misato Amamoto1, Tomohide Yamada², Kazuo Hara ${ }^{3}$
}

1. Internal Medicine Department, Endocrinology and Metabolism, Tokyo Metropolitan Tama Medical Center, Tokyo, Japan

2. Department of Diabetes and Metabolic Diseases, Graduate School of Medicine, University of Tokyo, Tokyo, Japan 3. Division of Endocrinology and Metabolism, Jichi Medical University, Saitama Medical Center, Saitama, Japan

\section{RESEARCH}

Please cite this paper as: Amamoto M, Hara K. Updated meta-analysis of the relation between heart disease and androgenic alopecia or alopecia areata. AMJ 2018;11(1):2533. https://doi.org/10.21767/AMJ.2017.3270

\section{Corresponding Author: \\ Misato Amamoto \\ Internal Medicine Department \\ Endocrinology and Metabolism \\ Tokyo Metropolitan Tama Medical Center, Tokyo, Japan \\ Email: misato.a.1029@gmail.com}

\section{ABSTRACT}

\section{Background}

The relationship between baldness and heart disease is still controversial. We performed an updated meta-analysis of observational studies to evaluate the relation between heart disease and androgenic alopecia or alopecia areata.

\section{Aims}

To evaluate the relation between heart disease and androgenic alopecia or alopecia areata.

\section{Methods}

Studies were identified by searching Medline and Embase up to October 20, 2017 without language restriction. Metaanalysis was performed by using a random-effects model.

\section{Results}

Nine studies were included in the meta-analysis (eight on androgenic alopecia and one on alopecia areata: 44,806 participants).
Compared to men without baldness, men with androgenic alopecia had an increased risk of heart disease (relative risk (RR): 1.32 , 95 per cent $\mathrm{Cl}: 1.08$ to $1.63, p=0.01, \mathrm{I}^{2}=25$ per cent), and younger men ( $<55$ or $\leq 60$ years) showed a stronger association (RR: 1.44, 95 per cent $\mathrm{Cl}: 1.11$ to 1.86 , $p=0.01, I^{2}=0$ per cent). The positive relation depended on the severity of baldness and decreased in order of severe vertex (RR: 1.60, 95 per cent $\mathrm{Cl}: 1.19$ to 2.16, $\mathrm{p}=0.002$ ), moderate vertex (RR: 1.41, 95 per cent $\mathrm{Cl}: 1.22$ to 1.64 , $p<0.001$ ), mild vertex (RR: $1.18,95$ per cent $\mathrm{Cl}: 1.05$ to 1.33 , $\mathrm{p}=0.007$ ), and frontal baldness (RR: 1.10, 95 per cent $\mathrm{Cl}$ : 0.92 to $1.32, p=0.28)$ ). In contrast, there was no significant relation between alopecia areata and heart disease (RR: 0.91, 95 per cent $\mathrm{Cl}: 0.60$ to $1.39, \mathrm{p}=0.66$ ).

\section{Conclusion}

Androgenic alopecia is associated with heart disease, but alopecia areata is not.

\section{Key Words}

Hair loss, scarring alopecia, alopecia areata, androgenic alopecia

\section{What this study adds:}

\section{What is known about this subject?}

The relationship between baldness and heart disease is still controversial.

\section{What new information is offered in this study?}

Androgenic alopecia is associated with an increased risk of heart disease particularly among younger men, but alopecia areata is not.

3. What are the implications for research, policy, or practice?

Androgenic alopecia is associated with systemic atherosclerosis. Thus, cardiovascular risk factors should be 
reviewed carefully in men with androgenic alopecia, especially younger men.

\section{Background}

"Hair loss" is a common clinical complaint that is a symptom of various disorders. The cause is easily diagnosed in many cases, such as in persons who present with classic male pattern hair loss or patchy hair loss due to alopecia areata.

Androgenic alopecia, also called male pattern baldness, is the most common type of hair loss in men, and affects approximately 50 per cent of Caucasian men by age 50 . It is characterized by progressive loss of terminal hairs on the scalp in a characteristic distribution. ${ }^{1,2}$

Alopecia areata is a chronic autoimmune disorder targeting anagen hair follicles that causes non-scarring hair loss. It most commonly presents with discrete patches of alopecia on the scalp. However, other areas may also be affected, and patients may lose all scalp or body hair in severe cases. $^{3-5}$

Our previously published meta-analysis ${ }^{6}$ showed a positive relationship between androgenic alopecia (male pattern baldness) and coronary heart disease. However, the relationship between alopecia areata and heart disease was not determined due to lack of suitable studies. Therefore, we performed an update of our systematic review and meta-analysis to assess the association of baldness (both androgenic alopecia and alopecia areata) with heart disease.

\section{Method}

\section{Search strategy}

The detailed methods were described in our previous report. Medline and Embase were searched from 1 January 1950 to 20 October 2017 using the medical subject headings 'baldness' ('baldness' or 'hair loss' or 'alopecia') and 'heart disease' ('coronary heart disease' or 'cardiovascular disease' or 'coronary artery disease') to identify observational studies that estimated the association between baldness and heart disease. The reference lists of all studies thus identified were also reviewed.

\section{Study selection}

We performed initial screening based on the study titles or abstracts, while the second screening process involved a full-text review. Cohort studies and cross-sectional studies that assessed the association between androgenic alopecia (or alopecia areata) and heart disease were eligible for inclusion if the following criteria were met: (1) the full text of the report was published in English, (2) the relative risk (RR) (risk ratio, hazard ratio, or odds ratio) was reported with adjustment for possible covariates (e.g., age, smoking, family history of baldness, or family history of heart disease), (3) the presence and severity of baldness was reported, and (4) heart disease events were reported.

\section{Definitions of baldness and heart disease}

Androgenic alopecia and alopecia areata were defined according to the description in the study and/or based on terms used by the authors. We excluded studies on other types of baldness (e.g., scarring alopecia). Heart disease was defined as including all the following: coronary artery disease, myocardial infarction, angina pectoris, cardiomyopathy, and other types of ischemic heart disease.

\section{Assessment of validity}

To ascertain the validity of the eligible studies, quality was appraised with reference to the STROBE statement. In addition, the Newcastle-Ottawa Scale for assessing the quality of non-randomized studies in meta-analyses was used to quantify the validity of each study.

\section{Data extraction}

Two investigators ( $\mathrm{MA}$ and $\mathrm{KH}$ ) independently reviewed each study to determine its eligibility, and then extracted and tabulated all of the relevant data. Disagreement was resolved by consensus. The following information was obtained from each study: first author, year of publication, type of study, country where the study was conducted, number of participants (all participants who participated in the study), heart disease events, method of assessing baldness, follow-up period, mean age, smoking, covariates for adjustment of analyses, and severity of baldness.

\section{Statistical analysis}

The pooled RR (adjusted for possible covariates) and its 95 per cent $\mathrm{Cl}$ were calculated for the risk of heart disease events in each study by the DerSimonian-Laird random effect model weighted with inverse variance. ${ }^{9}$ Cochrane's $\chi 2$ test and the $\mathrm{I}^{2}$ test were performed to evaluate heterogeneity among the studies. ${ }^{10}$ Possible publication bias was evaluated by creating a funnel plot of the effect size for each study versus the standard error (SE). Funnel plot asymmetry was assessed by the tests of Begg and Egger. ${ }^{11,12}$ All analyses were performed with Stata V.14.0 software (StataCorp, College Station, Texas, USA) and $p<0.05$ was considered significant. Results are expressed as the mean with 95 per cent $\mathrm{Cl}$, unless otherwise indicated. 


\section{Results}

We identified a total of 353 reports by searching the two databases. After further evaluation, nine studies fulfilled the criteria for the present meta-analysis $(44,806$ participants) (Figure 1). ${ }^{13-21}$

The nine studies included four cohort studies and five crosssectional studies, and their characteristics are summarized in Table 1. Eight studies investigated androgenic alopecia and one study assessed alopecia areata. Three studies used a modified Hamilton scale and one study used a simplified Hamilton scale. The RR of subjects with baldness for heart disease was adjusted for several coronary risk factors (age, smoking, diabetes, etc.) in each study, but the number of variables differed significantly among the studies.

All of the studies used in the present meta-analysis achieved at least six of nine points in the Newcastle-Ottawa quality assessment scale for observational studies.

\section{Androgenic alopecia and heart disease}

Analysis of the three cohort studies ${ }^{13-15}$ revealed that androgenic alopecia was associated with an increased risk of heart disease (RR: 1.32 , 95 per cent $\mathrm{Cl}: 1.08$ to 1.63 , $p=0.01, I^{2}=25$ per cent) compared to that for the subjects without baldness. When the analysis was restricted to younger men ( $<55$ or $\leq 60$ years), the association of baldness with heart disease became stronger (RR: 1.44, 95 per cent $\mathrm{Cl}$ : 1.11 to $1.86, \mathrm{p}=0.01, \mathrm{I}^{2}=0$ per cent) (Figure 2 ).

Analysis of the four cross-sectional studies ${ }^{16-19}$ yielded similar results for the risk of heart disease in subjects with versus without baldness (RR: 1.91, 95 per cent $\mathrm{Cl}: 1.21$ to 3.01, $p=0.005, I^{2}=81$ per cent), and analysis of younger men ( $<55$ or $\leq 60$ years) also showed a stronger association of baldness with heart disease (RR 2.04 (1.48 to 2.81, $p<0.001$, $\mathrm{I}^{2}=50$ per cent) (Figure 2 )

The positive association was dependent on the severity of baldness and decreased in the order of severe vertex (RR: 1.60, 95 per cent $\mathrm{Cl}: 1.19$ to 2.16, $\mathrm{p}=0.002$ ), moderate vertex (RR: 1.41, 95 per cent $\mathrm{Cl}: 1.22$ to $1.64, p<0.001$ ), mild vertex (RR: $1.18,95$ per cent $\mathrm{Cl}: 1.05$ to $1.33, p=0.007$ ), and frontal baldness (RR: 1.10, 95 per cent $\mathrm{Cl}: 0.92$ to 1.32 , $\mathrm{p}=0.28$ ) (Figure 3).

\section{Alopecia areata and heart disease}

One study ${ }^{21}$ (5,508 participants) was identified and it showed no significant relation between alopecia areata and heart disease (RR: 0.91, 95 per cent $\mathrm{Cl}: 0.60$ to $1.39, \mathrm{p}=0.66$ ) (Figure 4).

\section{Publication bias}

The funnel plot, Begg's test, and Egger's test were used to evaluate the influence of publication bias on the association between baldness and heart disease. The funnel plot did not show asymmetry, while Egger's test and Begg's test found no significant influence (data not shown).

\section{Discussion}

This up-dated meta-analysis demonstrated that androgenic alopecia was significantly associated with an increased risk of heart disease among men of all ages and particularly among younger men. In addition, the relationship between heart disease and androgenic alopecia was dependent on the severity of baldness. On the other hand, there was no significant relation between alopecia areata and heart disease, although only 1 relevant study was identified.

Meta-analysis showed a trend that people with severe baldness may be associated with higher risk of heart disease. Thus, the severity of baldness might have reflected the progression of atherosclerosis.

Several mechanisms could explain the positive association between androgenic alopecia and the risk of heart disease. Classical coronary risk factors might influence both conditions, making baldness a surrogate marker of atherosclerosis. Also, a positive association has been reported between androgenic alopecia and insulin resistance, ${ }^{22}$ metabolic syndrome, ${ }^{23}$ and hypertension. ${ }^{24}$ As we stated, ${ }^{6}$ mechanisms such as hyperinsulinemia/insulin resistance, $^{25}$ chronic inflammation, ${ }^{26}$ and increased peripheral sensitivity to androgens ${ }^{27}$ have also been suggested.

This meta-analysis had several limitations. While assessment of publication bias did not suggest that unpublished results had been missed, the analysis might have been underpowered due to the small numbers of studies. Also, between-study heterogeneity was significant for some factors, with differences of epidemiological characteristics or diagnostic criteria (for baldness and/or heart disease) probably contributing to heterogeneity.

The third limitation was incomplete information about medications that might have contributed to baldness. Fourth, the method of assessing baldness varied between studies, so we could not exclude other local (or systemic) causes of diffuse hair loss.

Due to insufficient data of alopecia areata and heart disease 
(only one research), there is no new information for this issue. Thus, update meta-analysis to assess the relationship between heart disease and alopecia areata is really required in the future.

\section{Conclusion}

In summary, this meta-analysis showed that androgenic alopecia is associated with heart disease, but alopecia areata is not. Further research is warranted to investigate differences between androgenic alopecia and alopecia areata in the mechanisms underlying the association with heart disease.

\section{References}

1. Ellis JA, Sinclair R, Harrap SB. Androgenetic alopecia: pathogenesis andpotential for therapy. Expert Rev Mol Med. 2002;4(22):1-11.

2. Price VH. Treatment of hair loss. N Engl J Med. 1999;341:964-73.

3. Huang KP, Mullangi S, Guo Y, et al. Autoimmune, atopic, and mental health comorbid conditions associated with alopecia areata in the United States. JAMA Dermatol. 2013;149(7):789-94.

4. Mirzoyev SA, Schrum AG, Davis MDP, et al. Lifetime incidence risk of alopecia areata estimated at $2.1 \%$ by Rochester Epidemiology Project, 1990-2009. J Invest Dermatol. 2014;134(4):1141-1142.

5. Ito T, Tokura Y. The role of cytokines and chemokines in the T-cell-mediated autoimmune process in alopecia areata. Exp Dermatol. 2014;23(11):787-91.

6. Yamada T, Hara K, Umematsu H, et al. Male pattern baldness and its association with coronary heart disease: a meta-analysis. BMJ Open. 2013;3(4). pii: e002537.

7. Von Elm E, Altman DG, Egger M, et al. The Strengthening the Reporting of Observational Studies in Epidemiology (STROBE) statement: guidelines for reporting observational studies. J Clin Epidemiol. 2008;61:344-9.

8. Wells G, Shea B, O'Connell D, et al. The NewcastleOttawa Scale (NOS) for assessing the quality of nonrandomised studies in meta-analyses [Internet]. Ottawa Hospital Research Institute. http://www.ohri.ca/programs/clinical_epidemiology/oxf ord.asp (accessed 24 August 2017).

9. DerSimonian R, Laird N. Meta-analysis in clinical trials. Control Clin Trials. 1986;7:177-88.

10. Higgins JP, Thompson SG. Quantifying heterogeneity in ameta-analysis. Stat Med. 2002;21:1539-58.

11. Begg CB, Mazumdar M. Operating characteristics of a rank correlation test for publication bias. Biometrics. 1994;50: 1088-101.

12. Egger M, Davey Smith $G$, Schneider $M$, et al. Bias in meta-analysis detected by a simple, graphical test. BMJ. 1997;315:629-34.

13. Schnohr P, Lange P, Nyboe J, et al. Gray hair, baldness, and wrinkles in relation to myocardial infarction: the Copenhagen City Heart Study. Am Heart J. 1995;130:1003-10.

14. Ford ES, Freedman DS, Byers T. Baldness and ischemic heart disease in a national sample of men. Am J Epidemiol. 1996;143:651-7.

15. Lotufo PA, Chae CU, Ajani UA, et al. Male pattern baldness and coronary heart disease: the Physicians' Health Study. Arch Intern Med. 2000;160:165-71.

16. Lesko SM, Rosenberg L, Shapiro S. A case-control study of baldness in relation to myocardial infarction in men. JAMA. 1993;269:998-1003.

17. Mirić D, Fabijanić D, Giunio L, et al. Dermatological indicators of coronary risk: a case-control study. Int J Cardiol. 1998;67:251-5.

18. Shahar E, Heiss G, Rosamond WD, et al. Baldness and myocardial infarction in men: the atherosclerosis risk in communities study. Am J Epidemiol. 2008;167(6):67683.

19. Sharma KH, Jindal A. Association between androgenetic alopecia and coronary artery disease in young male patients. Int J Trichology. 2014;6(1):5-7.

20. Park SY, Oh SS, Lee WS. Relationship between androgenetic alopecia and cardiovascular risk factors according to BASP classification in Koreans. J Dermatol. 2016;43(11):1293-1300.

21. Huang KP, Joyce $\mathrm{CJ}$, Topaz $\mathrm{M}$, et al. Cardiovascular risk in patients with alopecia areata (AA): A propensitymatched retrospective analysis. J Am Acad Dermatol. 2016;75(1):151-4.

22. Mumcuoglu C, Ekmekci TR, Ucak S. The investigation of insulin resistance and metabolic syndrome in male patients with early-onset androgenetic alopecia. Eur J Dermatol. 2011;21:79-82.

23. Su LH, Chen TH. Association of androgenetic alopecia with metabolic syndrome in men: a community-based survey. Br J Dermatol. 2010;163:371-7.

24. Ahouansou S, Le Toumelin P, Crickx B, et al. Association of androgenetic alopecia and hypertension. Eur J Dermatol. 2007;17:220-2.

25. Matilainen V, Koskela P, Keinänen-Kiukaanniemi S. Early androgenetic alopecia as a marker of insulin resistance. Lancet. 2000;356:1165-6.

26. Hirsso P, Rajala U, Hiltunen L, et al. Obesity and lowgrade inflammation among young Finnish men with early-onset alopecia. Dermatology. 2007;214:125-9.

27. Hibberts NA, Howell AE, Randall VA. Balding hair follicle dermal papilla cells contain higher levels of androgen 
receptors than those from non-balding scalp. J

Endocrinol. 1998;156:59-65.

\section{PEER REVIEW}

Not commissioned. Externally peer reviewed.

\section{CONFLICTS OF INTEREST}

The authors declare that they have no competing interests.

Figure 1: Literature search and study selection

\section{FUNDING}

None

ETHICS COMMITTEE APPROVAL

N/A
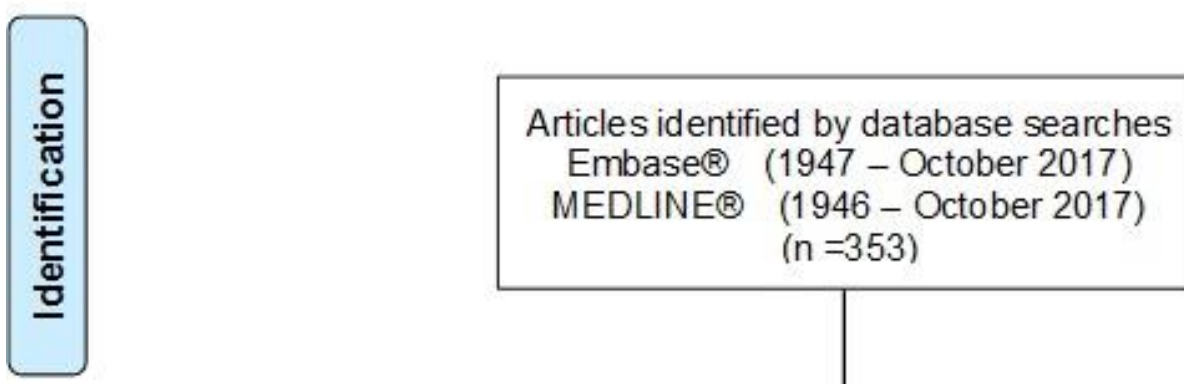

Articles identified by database searches

Embase $(8)$ (1947 - October 2017)

MEDLINE@ (1946 - October 2017) $(n=353)$
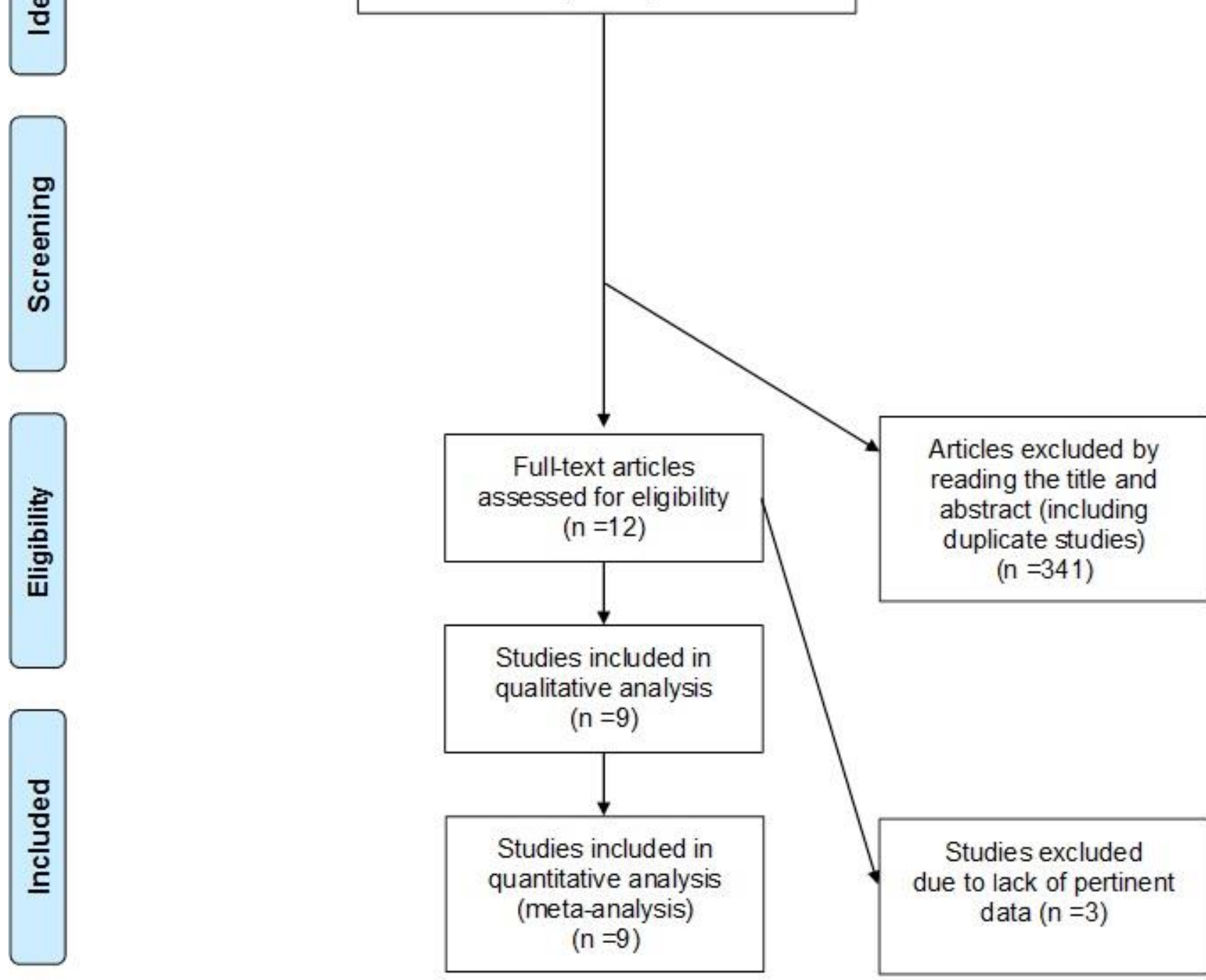
Figure 2: Association of androgenetic alopecia with heart disease in the observational studies

All subjects

Cohort studies

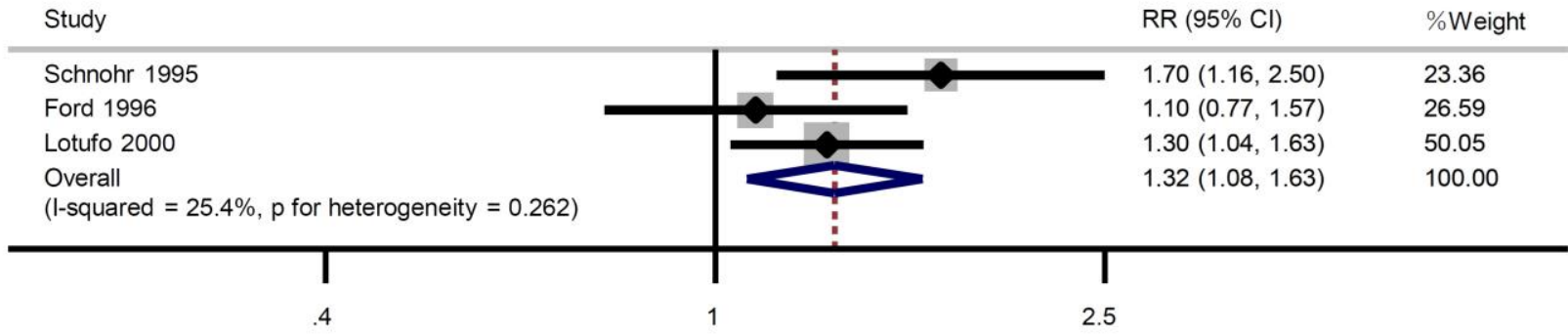

Cross-sectional studies

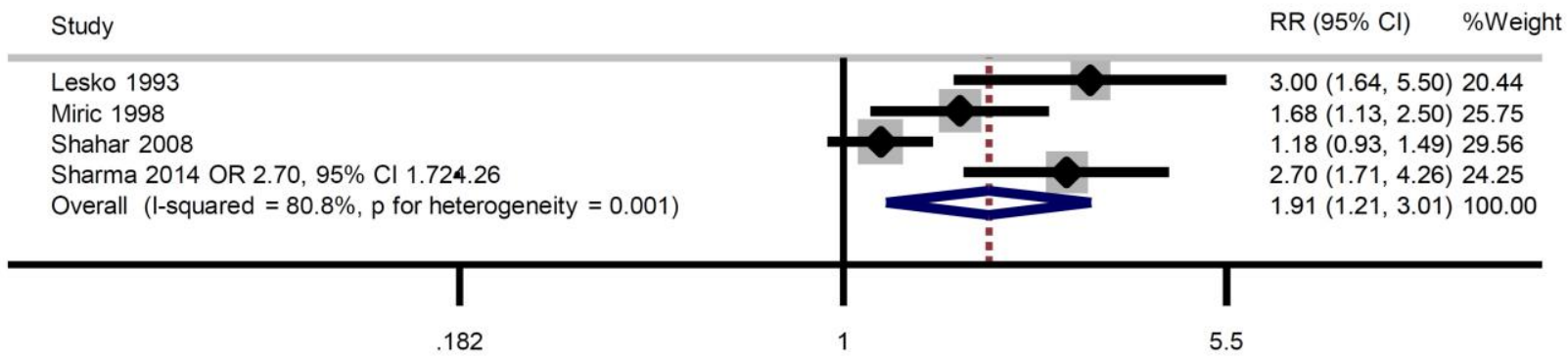

Patients $<55$ or $<=60$ years old Cohort studies

\begin{tabular}{|c|c|c|}
\hline Study & $\mathrm{RR}(95 \% \mathrm{Cl})$ & $\%$ Weight \\
\hline Schnohr 1995 & $1.60(0.98,2.60)$ & 28.64 \\
\hline Ford 1996 & $1.72(0.96,3.08)$ & 19.89 \\
\hline Lotufo 2000 & $1.26(0.88,1.81)$ & 51.46 \\
\hline Overall $(\mathrm{l}-$ squared $=0.0 \%, \mathrm{p}$ for heterogeneity $=0.589$ ) & $1.44(1.11,1.86)$ & 100.00 \\
\hline
\end{tabular}

Cross-sectional studies

\begin{tabular}{|c|c|c|}
\hline Study & $\operatorname{RR}(95 \% \mathrm{Cl})$ & \%Weigh \\
\hline $\begin{array}{l}\text { Lesko } 1993 \\
\text { Miric } 1998 \\
\text { Shahar } 2008 \\
\text { Sharma } 2014 \text { OR } 2.70,95 \% \mathrm{Cl} 1.724 .26 \\
\text { Overall (I-squared }=49.8 \%, \mathrm{p} \text { for heterogeneity }=0.113 \text { ) }\end{array}$ & $\begin{array}{l}3.00(1.64,5.5 \\
1.68(1.13,2.5 \\
1.52(1.03,2.2 \\
2.70(1.71,4.2 \\
2.04(1.48,2.8\end{array}$ & $\begin{array}{l}17.94 \\
28.40 \\
28.73 \\
24.93 \\
100.00\end{array}$ \\
\hline
\end{tabular}


Figure 3: Association of androgenetic alopecia with heart disease stratified by the severity of baldness

Severe vertex vs. non-balding

\begin{tabular}{|c|c|c|c|}
\hline Study & & RR (95\% Cl) & \%Weight \\
\hline $\begin{array}{l}\text { Lotufo } 2000 \\
\text { Lesko } 1993 \\
\text { Shahar } 2008 \\
\text { Sharma } 2014 \\
\text { Park } 2016 \\
\text { Overall (I-squared }=63.5 \%, p \text { for heterogeneity }=0.027 \text { ) }\end{array}$ & $\longrightarrow$ & $\begin{array}{l}1.30(1.04,1.63) \\
3.00(1.64,5.50) \\
1.18(0.93,1.49) \\
2.36(1.04,5.33) \\
1.87(1.03,3.37) \\
1.60(1.19,2.16)\end{array}$ & $\begin{array}{l}30.38 \\
14.65 \\
30.05 \\
9.86 \\
15.07 \\
100.00\end{array}$ \\
\hline $\begin{array}{c}1 \\
182\end{array}$ & & & \\
\hline
\end{tabular}

Moderate vertex vs. non-balding

\begin{tabular}{|c|c|c|}
\hline Study & $\operatorname{RR}(95 \% \mathrm{Cl})$ & \%Weight \\
\hline Lotufo 2000 & $1.33(1.09,1.62)$ & 54.45 \\
\hline Lesko 1993 & $1.40(0.85,2.30)$ & 8.60 \\
\hline Shahar 2008 & $1.40(1.05,1.86)$ & 26.24 \\
\hline Park 2016 & $2.01(1.29,3.13)$ & 10.71 \\
\hline Overall (I-squared $=0.0 \%, p$ for heterogeneity $=0.430$ ) & $1.41(1.22,1.64)$ & 100.00 \\
\hline 1 & & \\
\hline .319 & & \\
\hline
\end{tabular}

Mild vertex vs. non-balding

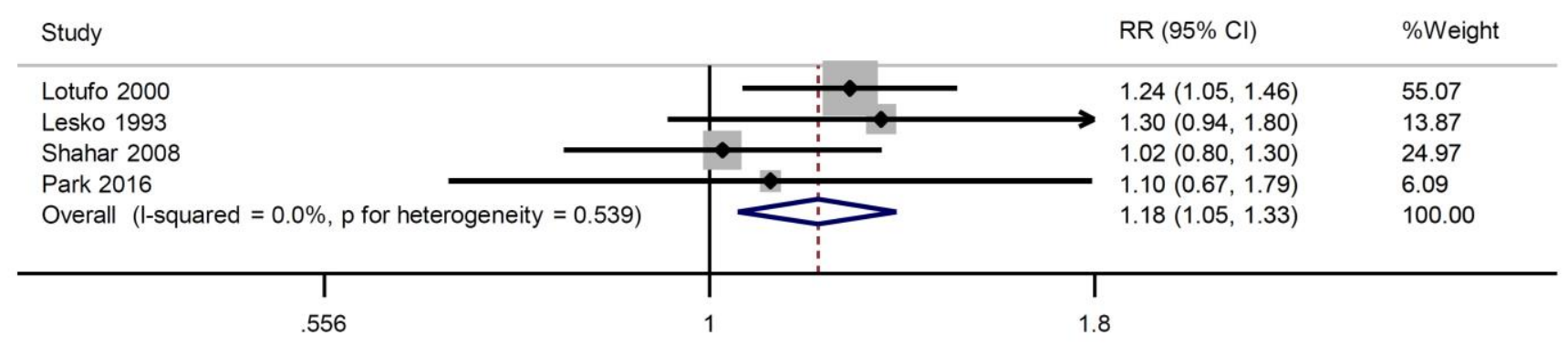

Frontal baldness vs. non-balding

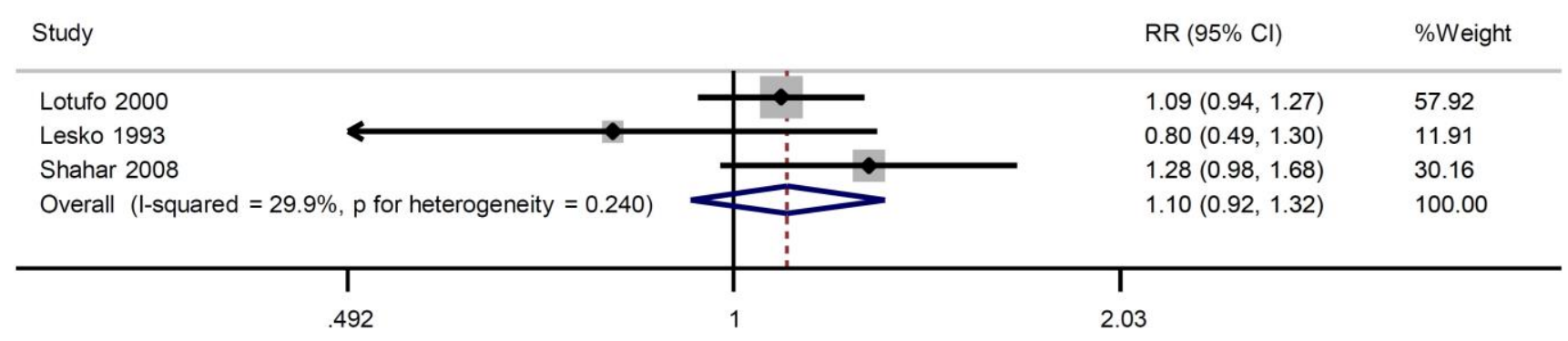


Figure 4: Association of alopecia areata with heart disease in the observational studies

Study

$\operatorname{RR}(95 \% \mathrm{Cl}) \quad \%$ Weight

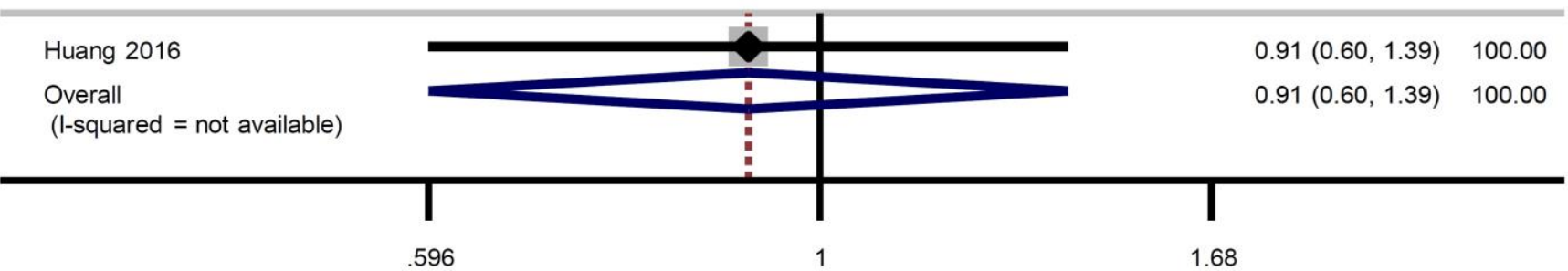

Table 1: Characteristics of the studies included in the meta-analysis

\begin{tabular}{|c|c|c|c|c|}
\hline $\begin{array}{l}\text { First author, } \\
\text { year, Type } \\
\text { of study, } \\
\text { Country }\end{array}$ & $\begin{array}{l}\text { Participants, } \\
\text { CHD (events) }\end{array}$ & $\begin{array}{l}\text { Assessment of Follow- } \\
\text { up baldness (years) }\end{array}$ & Covariates used for adjustment & $\begin{array}{l}\text { NOS } \\
\text { score }\end{array}$ \\
\hline \multicolumn{5}{|c|}{ Androgenic alopecia } \\
\hline $\begin{array}{l}\text { Schnohr, } \\
\text { 1995, } \\
\text { Cohort, } \\
\text { Denmark }^{13}\end{array}$ & 5837, MI (524) & $\begin{array}{l}\text { Simplified Hamilton } \\
\text { (none, frontoparietal, } \\
\text { crown-top, combined), } \\
12\end{array}$ & $\begin{array}{l}\text { Age, smoking, systolic blood pressure, cholesterol, } \\
\text { triglycerides, physical activity, BMI, family history of } \\
\text { MI, marital status, education, economic status, } \\
\text { diabetes and alcohol consumption }\end{array}$ & 8 \\
\hline $\begin{array}{l}\text { Ford, 1996, } \\
\text { Cohort, The } \\
\text { USA }^{14}\end{array}$ & $\begin{array}{l}\text { 3994, } \\
\text { Ischaemic } \\
\text { heart disease } \\
(965)\end{array}$ & $\begin{array}{l}\text { Personal scale (none, } \\
\text { minimum, moderate, } \\
\text { severe), } 14\end{array}$ & $\begin{array}{l}\text { Age, age squared, race, education, systolic blood } \\
\text { pressure, antihypertensive medication, cholesterol, } \\
\text { smoking, BMI and diabetes mellitus }\end{array}$ & 8 \\
\hline $\begin{array}{l}\text { Lotufo, } \\
2000, \\
\text { Cohort, The } \\
\text { USA }^{15}\end{array}$ & $\begin{array}{l}19112, \text { Non-fatal } \\
\text { MI, angina, } \\
\text { coronary } \\
\text { revascularisation } \\
(1446)\end{array}$ & $\begin{array}{l}\text { Modified Hamilton } \\
\text { (none, frontal, mild } \\
\text { vertex, moderate vertex, } \\
\text { severe vertex), } 11\end{array}$ & $\begin{array}{l}\text { Age, aspirin assignment, } \beta \text {-carotene assignment, } \\
\text { BMI, height }(\mathrm{cm}) \text {, hypertension, } \\
\text { hypercholesterolaemia, diabetes, parental history of } \\
\text { MI, physical activity, smoking and alcohol use }\end{array}$ & 8 \\
\hline $\begin{array}{l}\text { Lesko, 1993, } \\
\text { Case- } \\
\text { control, The } \\
\text { USA }^{16}\end{array}$ & $\begin{array}{l}\text { 1437, Non-fatal } \\
\text { MI (665) }\end{array}$ & $\begin{array}{l}\text { Modified Hamilton } \\
\text { (none, frontal only, mild } \\
\text { vertex, moderate vertex, } \\
\text { severe vertex) }\end{array}$ & $\begin{array}{l}\text { Age, race, religion, years of education, BMI, use of } \\
\text { alcohol and cigarettes, family history of MI, personal } \\
\text { history of angina, hypertension, diabetes, } \\
\text { hypercholesterolaemia, gout, exercise, personality } \\
\text { and number of doctor visits in the past year }\end{array}$ & 6 \\
\hline $\begin{array}{l}\text { Mirić, } 1998, \\
\text { Case- } \\
\text { control, }^{17} \\
\text { Croatia }^{17}\end{array}$ & $\begin{array}{l}\text { 1554, Non-fatal } \\
\text { MI (842) }\end{array}$ & $\begin{array}{l}\text { Personal score (none, } \\
\text { any, frontal, parietal, } \\
\text { frontoparietal) }\end{array}$ & $\begin{array}{l}\text { Age, family history of } \mathrm{MI} \text {, hypertension, } \\
\text { hypercholesterolaemia, BMI, diabetes and smoking }\end{array}$ & 7 \\
\hline $\begin{array}{l}\text { Shahar, } \\
2008, \text { Case- } \\
\text { control, The } \\
\text { USA }^{18}\end{array}$ & $\begin{array}{l}\text { 5056, Non-fatal } \\
\text { MI (767) }\end{array}$ & $\begin{array}{l}\text { Modified Hamilton } \\
\text { (none, frontal, mild } \\
\text { vertex, moderate vertex, } \\
\text { severe vertex) }\end{array}$ & $\begin{array}{l}\text { Age, smoking, BMI, race-centre, cholesterol-lowering } \\
\text { medication, antihypertensive medication, } \mathrm{HDL} \text {, } \\
\text { diabetes, educational level and family history of } \mathrm{MI}\end{array}$ & 8 \\
\hline $\begin{array}{l}\text { Sharma, } \\
2014, \text { Case- } \\
\text { control, } \\
\text { India }^{19}\end{array}$ & $\begin{array}{l}\text { 424, coronary } \\
\text { artery } \\
\text { disease(212) }\end{array}$ & $\begin{array}{l}\text { Hamilton scale(none, } \\
\text { low, high), - }\end{array}$ & - & 6 \\
\hline $\begin{array}{l}\text { Park, 2016, } \\
\text { Case- } \\
\text { control, } \\
\text { Korea }^{20}\end{array}$ & $\begin{array}{l}\text { 1884, } \\
\text { cardiovascular } \\
\text { disease(129) }\end{array}$ & $\begin{array}{l}\text { BASP classification(none, } \\
\text { mild, moderate, severe), } \\
\text { - }\end{array}$ & - & 7 \\
\hline
\end{tabular}




\section{Alopecia areata}

Huang, 5508, MI(116)

Age, gender, race, smoking status, diabetes,

8

2016, Case-

control,

The USA $^{21}$

hyperlipidemia, hypertension

BMI, body mass index; CHD, coronary heart disease; HDL, high-density lipoprotein; MI, myocardial infarction; NOS, Newcastle Ottawa Scale 